\title{
Market Orientation in Small and Medium Enterprises: Determinants and Implications for Enterprise Development (Evidence from Addis Ababa, Ethiopia)
}

\author{
Alemseged Gerezgiher Hailu* \\ Center for Rural Development, Addis Ababa University, P.O.Box: 150572, Addis Ababa, Ethiopia \\ Tewodros Wuhib Woldemariam \\ Department of Management, Addis Ababa University
}

\begin{abstract}
Market orientation has attracted considerable attention in academics and from industry practitioners in the last three or so decades and pretty many studies have been conducted in this area. Except few, such studies have been conducted in large firms and in developed countries. Such research is either missing in least developed countries such as Ethiopia and emerging countries and on small and medium firms or little (if any) with limited coverage and significance. The Ethiopian small and medium enterprises sector has not been adequately studied empirically in this regard. These reasons gave the rationale to conduct the current research. Thus, the study aimed at investigating the determinants of and benefits of market orientation in small and medium enterprises in Addis Ababa City in terms of firm performance. Descriptive and cause-effect designs were used to achieve the objectives of the study. Data were collected using standardized instrument and measurements from 200 randomly selected respondents drawn from manufacturing small and medium enterprises. Statistical tools and econometric models were employed to undertake quantitative analysis. Descriptive findings of the study indicated that the sample enterprises were slightly market oriented. Besides, the study revealed that market orientation is affected by operators' characteristics and enterprise features. The study also showed that market orientation and its constructs have strong and significant relationships with the indicators of enterprises' performance. Indeed, market orientation has significant and positive effect on enterprises' sales growth, long term focus and profit emphasis. In conclusion, the study has immense implications in terms of adding insights to the existing body of literature because it tested some hypotheses held in the literature and generated confirmatory results, and for managerial practices of small and medium enterprises. It also has implications for responsible government offices to reorient their business development services and training supports provided to small enterprises so as to make them more market oriented.
\end{abstract}

Keywords: market orientation, small and medium enterprises, firm performance, Ethiopia

DOI: $10.7176 / \mathrm{DCS} / 9-7-01$

Publication date:July $31^{\text {st }} 2019$

\section{The Research Problem and Its Context}

Small and medium sized enterprises (hereafter SMEs) contribute significantly to the socio-economic development of countries. They are regarded as engines of economic growth in terms of job creation, mobilizing resources, income generation and thereby poverty reduction among others. In connection to this idea, Mohammad (2006) stated that SMEs are crucial in that they are relatively high labour intensity; they depend on indigenous skills and technology, contribute to entrepreneurship development and innovativeness and contribute to the growth of industrial linkages by referring to Uddin (2001) and McCaran-Quinn and Carson (2003). Dey (2012) also affirmed this claim in his empirical study.

Competitive performance of these enterprises in the market is a key factor for their failure or success. Factors contributing to the competitive performance of small and medium-sized firms have long been attracting the attention of researchers, policy makers and business owners/managers. But, for these enterprises to deliver what is expected of them, they have to be market oriented. As empirical research suggests, a market-oriented organizational culture may work as a critical driver of superior performance for SMEs. Various researches in management highlight strategic, structural, managerial, cultural and procedural aspects as antecedents of high performance in SMEs. According to the findings of Pelham (2000), for instance, market-oriented SMEs are more likely to achieve superior financial performance particularly if they follow a growth/differentiation strategy. Similarly, Smallbone et al. (1995) found out that high performance SMEs benefit largely from a market-oriented culture, particularly when it is coupled with a differentiation and/or low cost strategy. A study by Yilmaz et al. (2005), in the Turkish business cultural context, revealed that customer orientation (as a component of market orientation) increases corporate financial performance substantially. According to Alpkan et al. (2007), numerous authors have noted that SMEs can overcome the size and efficiency related advantages of larger scale firms, such as market power, economies of scale, broad product lines, and superior production technology, by becoming more 
market oriented.

Indeed, market orientation has attracted considerable attention in academics and from industry practitioners in the last three or so decades. In fact, pretty many studies have been conducted on this area, such as market orientation and innovation (Henard \& Szymanski, 2001), market orientation and firm performance (Kohli \& Jaworski, 1990; Narver \& Slater, 1990), and market orientation and firm competitive advantage (Lumpkin \& Dess, 2001). However, these lines of research mainly focused on large firms and, in, developed countries.

The role of the SME sector in employment creation, economic growth and poverty alleviation has received the recognition it deserves, as it is explicitly stated in all strategies of the Government of Ethiopia. Accordingly, the Government of Ethiopia developed two consecutive micro, small and medium enterprises strategies in 1997 and 2011 to aid the establishment and promotion of such enterprises (Federal Democratic Republic of Ethiopia, Ministry of Trade and Industry (MoTI), 1997; Federal Democratic Republic of Ethiopia, Federal Micro and Small Enterprises Development Agency (FeMSEDA), 2011). Since inception of the first formal strategy, large numbers of enterprises have been established in the country, which have created substantial job opportunities and mobilized financial and non-financial resources (National Bank of Ethiopia (NBE), 2015). This is taken as success story in enterprise development in the country.

However, the government's focus is on new establishments of enterprises and provision of mainstream services such as loan services and other business development services. Thus, despite the hope placed in such enterprises; and the support strategies and programs designed, micro, small and medium enterprises' failure rate is incredibly high in the country (Joshi \& Gebreselassie, 2016; Tesfaye, 2016; Belay et al., 2015; Zeleke, 2013; Eshetu, 2008). Although such failure tends to be high in the early stages of the enterprises, it is also prevalent in later stages (Mesfin, 2015). This high failure rate is becoming a concern of many in the academic and government sections and, therefore, subject of investigation these days. Sustainability and promotion to the next higher stages is left void in the strategies pertaining to small enterprises. Such questions as why failure rate is as such high in micro, small and medium enterprises (MSMEs) and why MSMEs are continuing as status quo amid the country's aspiration to be middle income in the foreseeable future do require rigorous scientific investigation.

Researchers (e.g., Joshi \& Gebreselassie, 2016; Tesfaye, 2016; Zeleke, 2013; Eshetu, 2008) identified several internal and external factors that contribute to high failure rate. The former incorporates such factors as age, size, scale and scope of operation of the enterprise, and financial incapability, and the latter group consists of lack of access to credit, lack of (proper) premises, lack of access to technologies and raw materials, and lack of good governance.) However, the emphasis given to marketing related factors is low. The market where such enterprises send their products is characterized by cutthroat competition, identical products in the same market and rampant change in consumer demand. These factors are very important determinants of success/failure rate of MSMEs but are more or less neglected in the Government's intervention. A retrospective view on the micro and small enterprises (MSEs)' strategy of the 2011 (see FeMSEDA, 2011) shows that the government's strategy is about creating market access and linkages. The strategy failed to instil a sustainable business and marketing philosophy in enterprise operators. This has created dependency syndrome among the operators. That is, they produce and wait until the government unlocks some market opportunities. If the government fails to do so, the operators' response is a pool of complaints that the government ignored them. Thus, it is the argument of this study that less is done in changing the business philosophy of operators and managers of MSMEs. Therefore, one of the missing points in the MSMEs' development in the country is market orientation.

Against this backdrop, given the economic and social significance of SMEs, conducting a study on their market orientation in order to add some knowledge to the literature and draw policy implications for government and managers is a remarkable contribution. Such research is either missing in least developing countries such as Ethiopia and emerging ones, and on small and medium firms or little (if any) with limited coverage and significance. The Ethiopian SME sector has not been adequately studied empirically in this regard. These gave the rationale to undertake a research, of this kind, on this area in developing countries and on SMEs. Therefore, the study is expected to contribute to both theory and practice in the growing literature of market orientation studies in the country and beyond. This study aimed at investigating the status of market orientation, its determinants and implications for firm performance (enterprise development) in SMEs in Addis Ababa, Ethiopia.

\section{Literature Review}

\subsection{Significance of Small and Medium Enterprises in Economic Development}

There is a growing economic significance of the SMEs as sources of new business creation, technology development and employment generation in both developing and developed countries (Dey, 2012; Helmsing, 2003). In fact, SMEs contribute greatly to the economies of all countries, regardless of their level of development. For example, about $80 \%$ of the labor force in Japan and $50 \%$ of workers in Germany are employed in the SME sector. With respect to developing countries, the International labor organization (ILO) stated in 1998 that the sector made a significant contribution to the gross domestic product of Uganda (20\%), Kenya (19.5\%) and Nigeria $(24.5 \%)$. 
In Ethiopia, both academics and the government acknowledge the significance of small and medium enterprises in the economy of the country. As stated by Mulatu et al. (2006), SMEs play an important role in Ethiopian economy, typically contributing over $99 \%$ of all enterprises, over $60 \%$ of private sector employment, and about $30 \%$ or so of exports. The Government of Ethiopia holds that such enterprises are vehicles for the realization of an unprecedented development of the country (FeMSEDA, 2011). They create more job opportunities, help mobilize resources, encourage entrepreneurial spirit and innovations, and feed larger manufacturers and service companies (Munira, 2012; Netsanet, 2009; Hibret, 2009; Eshetu \& Zeleke; 2008; Solomon, 2004). Indeed, the MSEs sector is the second largest sector in generating employment opportunities in the country (Aregawi \& Tilaye, 2014). This is vital as the country's economy is agriculture based, traditional and with limited social and economic opportunities. Accordingly, the country gave high attention to the sector in all development strategies particularly in a plan for accelerated and sustainable development to end poverty (PASDEP), growth and transformation plan (GTP) I and II (see Federal Democratic Republic of Ethiopia (FDRE), 2006; FDRE, 2010; FDRE, 2015). Based on this, the country has registered remarkable growth in new establishments MSEs and job creation.

According to annual report of the national bank of Ethiopia (NBE, 2015), the country has recorded significant achievement in terms of new MSE establishments, capital mobilization as well as job creation in the last years of PASDEP and the GTP I period.

MSE establishments (NBE, 2014/15)

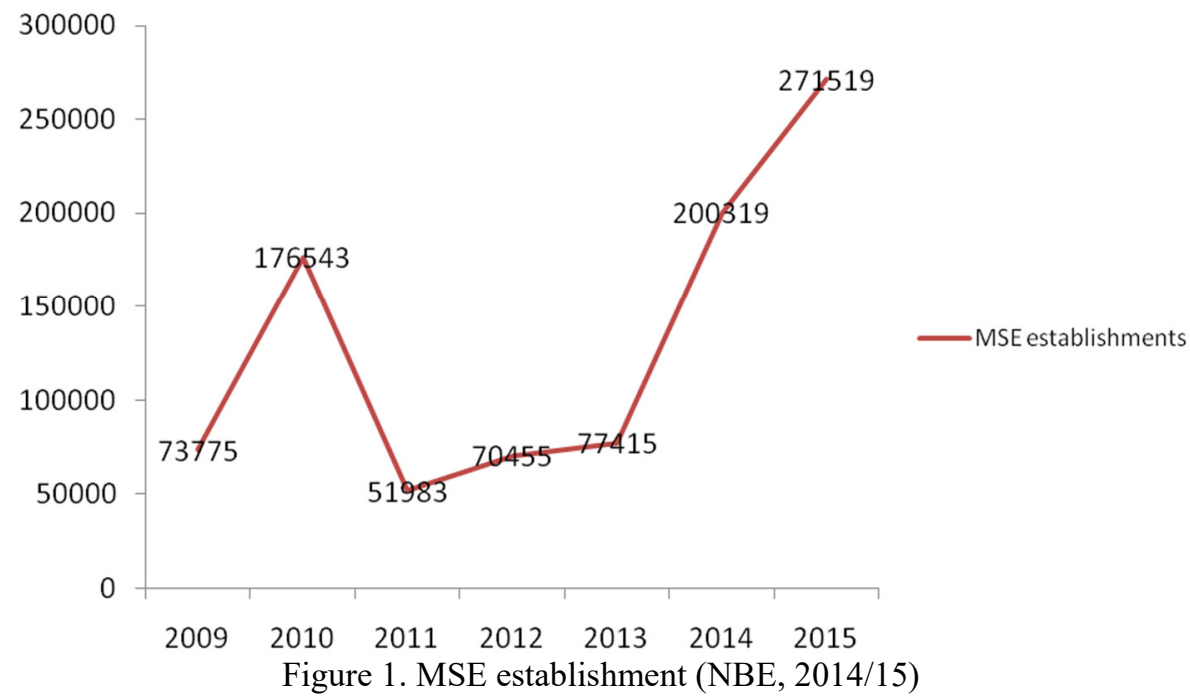

As it is indicated in the figure above, new MSE establishments grew from 73,775 enterprises in 2009 to 271,519 new enterprises in 2015 resulting in a growth rate of more than $268 \%$. In absolute terms, the growth in new establishments during the GTP period is high. Substantial amount of loan was granted to these new establishments as indicated in the following figure.

\section{Loan provided in Million (NBE, 2014/15)}

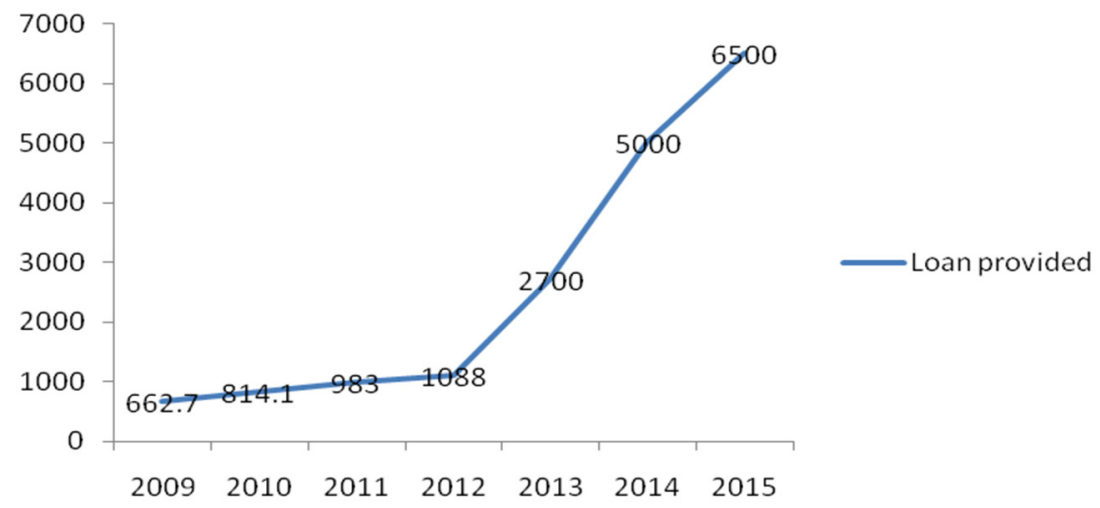

Figure 2. Amount of Loan Provided to MSEs (NBE, 2014/15)

The amount of loan provided to the new establishment of enterprises grew from as small as 662.7 million Birr in 2009 to 6.5 Billion Birr at the end of 2014/25. This shows the significance of MSEs in mobilizing financial resources and making meaningful investment. Furthermore, these enterprises created significant number of jobs and substantially contributed to the economy of the country. 


\section{Jobs Created (NBE, 2014/15)}

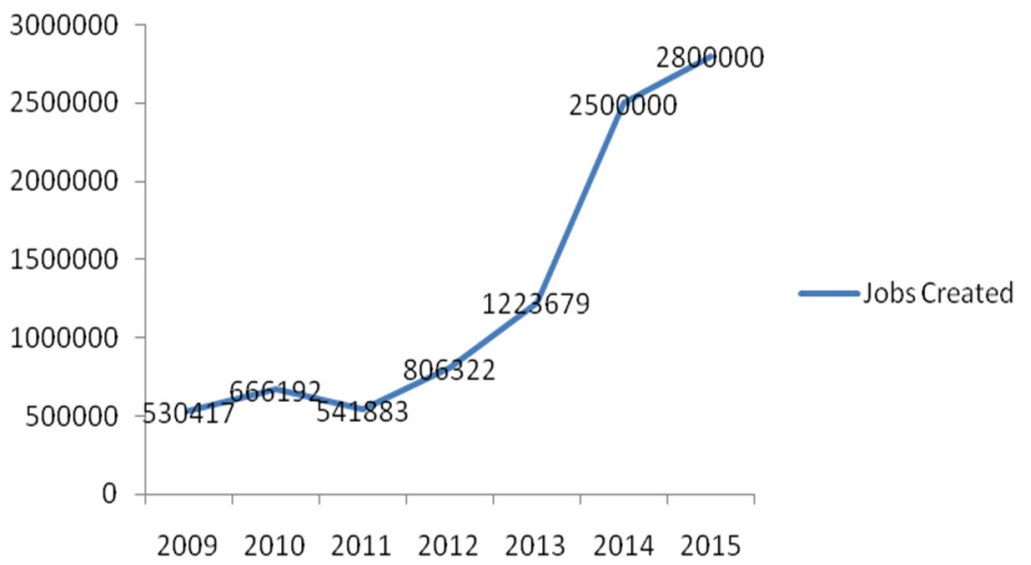

Figure 3. Jobs Created by MSEs (NBE, 2014/15)

Similarly, the number of jobs created by the new establishments of MSEs has grown from 530,417 jobs in 2009 to 2.8 million in 2015 . The number of new jobs has increased by $427.9 \%$ during this period. This shows the extent of significance of MSMEs in the Ethiopian economy.

\subsection{The Concept of Market Orientation}

The concept of market orientation has its roots in marketing studies. In fact, marketing has been defined by many scholars in different ways. However, for the purpose of this research, we are limited to the following. Marketing is a social and managerial process by which individuals or groups obtain what they need and want through creating, offering and exchanging of product of values with others (Kotler \& Armstrong, 2012). Marketing is the activity, set of institutions, and processes for creating, communicating, delivering, and exchanging offerings that have value for customers, clients, partners, and society at large (American Marketing Association, 2007). Marketing activities aim at developing and delivering products based on customer needs. Identifying the customer preference is the primary and sole activity of every organization. In order to survive, have sustainable growth, maintain long lasting relations and overcome the cutthroat competition, the role of marketing is indispensable in these days' business organizations. Thus, the central tent of marketing is dwelling through identifying and delivering products based on customer needs and wants via increasing the customer satisfaction for sustainable and profitable relations.

Indeed, marketing has passed through different phases both in terms of philosophy, theory and practices since its modern conception. Marketing scholars have identified five evolving marketing management philosophies to date.

Table 1: Marketing Philosophies

\begin{tabular}{|c|c|}
\hline $\begin{array}{c}\text { Marketing } \\
\text { thinking }\end{array}$ & Emphasis \\
\hline Production concept & $\begin{array}{l}\text { - } \quad \text { Consumers favor products that are available and affordable } \\
\text { - } \quad \text { Management focuses on improving production and distribution efficiency } \\
\text { - } \quad \text { Works well when demand exceeds supply }\end{array}$ \\
\hline Product concept & $\begin{array}{l}\text { - Consumer favor products with best quality, performance, innovative features } \\
\text { - Improving product features in a continuous fashion is management's orientation } \\
\text { - It works well if the market is stable, and if there are no competing technologies in } \\
\text { sight }\end{array}$ \\
\hline Selling concept & $\begin{array}{l}\text { - Consumers will not buy enough products unless seller(s) undertake large-scale } \\
\text { promotion and selling effort } \\
\text { - Emphasis is on promoting product, coaxing people into buying } \\
\text { - Works for unsought goods - encyclopedias, insurance }\end{array}$ \\
\hline Marketing concept & $\begin{array}{l}\text { - } \quad \text { A rational consumer buys product that best satisfies needs and wants } \\
\text { - } \quad \text { Marketers determine needs and wants of target markets } \\
\text { - } \quad \text { Deliver the desired satisfaction more effectively and efficiently than competitors }\end{array}$ \\
\hline $\begin{array}{l}\text { Societal marketing } \\
\text { concept }\end{array}$ & $\begin{array}{l}\text { - Emphasis is on balancing (1) Consumer satisfaction in short and long term, (2) } \\
\text { society, (3) company profits }\end{array}$ \\
\hline
\end{tabular}

Source: synthesized based on Kotler (2012) and Kotler and Kelly (2016) 
Many also misunderstood marketing as they believe it is limited to selling and promoting. However, marketing goes beyond selling and promotion. Its central tent is identifying and delivering products based on customer needs and wants via increasing customer satisfaction for sustainable and profitable relations. Pursuant to this, the main activity of a company is satisfying its customers through producing the product based on their needs and wants, providing exuberant service, providing the product at affordable price by customer, delivering the product at convenience location (to minimize customers' cost) and informing the customers about their offer by spotting on the key benefit the customers derive from using the company's product.

The marketing concept has been regarded as an important philosophy and tool for profitable marketing practices. McKitterick (1957), Felton (1959), and Keith (1960) conceptualizes the marketing concept as a corporate state of mind that insists on the integration and coordination of all the marketing functions that, in turn, are melded with all other corporate functions, for the sole purpose of producing maximum long-range corporate profits. McNamara (1972) regards the marketing concept as a business philosophy, an idea or a policy statement. Houston (1986) defines the concept as a willingness to recognize and understand consumers' needs and wants, and a willingness to adjust any of the marketing mix elements to satisfy those needs and wants.

The concept of market orientation (MO) has evolved from the conceptualization of the marketing concept. Market orientation is a framework for implementing the marketing thinking/concept, and its study originated in the early 1990's. It has been conceptualized and defined by various authors. To account few of the definitions, we made review of the following sources and the respective contents. For instance, market orientation is described as an organizational culture that focuses on "delivering products and services valued by customers, usually accomplished through ongoing monitoring of market conditions, and adaptation of organizational responses" (Grewal \& Tansuhaj, 2001: 67 as cited in Alpkan et al., 2007). It can also be defined as a form of organizational culture where employees throughout the organization are committed to continuously create superior customer value, or as a sequence of marketing activities that lead to better performance (Schalk, 2008). According to Kohli and Jaworski (1990), a firm exhibiting market orientation engages in the generation of market intelligence, disseminates this intelligence throughout the organisation, and develops effective strategies in response to this information. Pelham and Wilson (1996) assert that a market-oriented culture is the main source of competitive advantage facilitating customer-driven value creation. However, being market oriented suggests much more than being simply customer led in that it entails an organization-wide focus not only on customers but also on all marketplace actors (e.g. competitors). This requires effective inter-functional coordination, is long term in focus and proactive in nature (Slater \& Narver, 1998).

It can be generalized from these definitions that market orientation is more than simply 'getting close to the customer'. An organization can be market oriented only if it completely understands its market. Customer information must go beyond research and promotional functions to permeate every organizational function. Market orientation is generally regarded as the implementation of the 'marketing concept'. It is the organization culture (i.e., culture and climate, Deshpande and Webster, 1989) that most effectively and efficiently creates the necessary behaviours for the creation of superior value for buyers and, thus, continuous superior performance for the business (Aaker, 1988; Kohli \& Jaworski 1990; Kotler, 1984; Kotler \& Andreasen 1987; Peters \& Austin, 1985; Peters, Waterman \& Jones, 1982; Shapiro, 1988; Webster, 1988). Generally, marketing orientation refers to a business culture in which organizations strive to create superior value for their customers (and superior performance for the business) by focusing on customer needs and long-term profitability (Becherer, Halstead \& Haynes, 2003). A market-oriented firm continuously monitors customers' changing needs and attempts to satisfy those needs by modifying its total offerings. Given that customers' satisfaction may to a large extent depend on the competitive offerings, it seems reasonable to expect that market orientation will have a stronger impact on customer satisfaction when the level of market orientation at the industry level is low.

Narver and Slater (1990) concluded that market orientation consists of three behavioural components customer orientation, competitor orientation, and inter-functional coordination - and two decision criteria - longterm focus and profit emphasis. They conceptualized an organization's degree of market orientation as the sum total of its emphasis on these five components.

\subsubsection{Customer Orientation}

At the heart of market orientation is customer focus. Customer orientation requires that a seller understands a buyer's entire value chain (Day \& Wensley, 1988), not only as it is today but also as it will evolve over time being subject to internal and market dynamics. Creating superior value for buyers continuously requires that a seller understands a buyer's entire value chain. Buyer value can be created at any point in the chain by making the buyer either more effective in its markets or more efficient in its operations. Employees of market-oriented businesses spend considerable time with their customers. Managers and employees throughout the business call on their customers or bring them into their own facilities in a constant search for new ways to satisfy their needs. Marketdriven businesses continuously monitor their customer commitment by making improved customer satisfaction as an on-going objective. To maintain the relationships that are critical to delivering superior customer value, they pay close attention to service both before and after sales. Because of the importance of employees in this effort, 
these businesses take great care to recruit and retain the best people available and provide them with regular training. Some businesses even involve their customers in hiring, training, and developing contact people as well as in making motivation and reward system decisions. Involving customers in these key areas forges strong customer loyalty.

It is established in the literature that customer orientation is mainly focused on showing commitment to customers, creating services that offer value for customers, understanding customers' needs, having customer satisfaction as a major objective, measuring customer satisfaction, and providing follow up services. A seller creates value for a buyer in only two ways: increasing benefits to the buyer in relation to the buyer's costs and decreasing the buyer's costs in relation to the buyer's benefits. A seller must understand not only the cost and revenue dynamics of its immediate target buyer firms, but also the cost and revenue dynamics facing the buyers' buyers, from whose demand their demand in the immediate market is derived. Hence, a seller must understand the economic and political constraints at all levels in the channel. Only with such a comprehensive framework can a seller understand who its potential customers are at present as well as who they may be in the future, what they want now as well as what they may want in the future, and what they perceive now as well as what they may perceive in the future as relevant satisfiers of their wants.

\subsubsection{Competitor Orientation}

Creating superior customer value requires more than just focusing on customers. The key questions are which competitors, and what technologies, and whether target customers perceive them as alternate satisfiers. Superior value requires that the seller identify and understand the principal competitors' short-term strengths and weaknesses, and long-term capabilities and strategies. According to Slater and Narver (1994), a competitor-focus entails gathering intelligence on three main questions: (1) who are the competitors? (2) what technologies do they offer? and (3) do they represent an attractive alternative from the perspective of the target customers? Using target rivals as a frame of reference, competitor-focused firms seek to identify their own strengths and weaknesses and to keep pace with or stay ahead of the rest of the field (Han, Kim \& Srivastava, 1998).

Ideally, firms should seek to understand both customers and competitors and to incorporate such knowledge in their strategic planning efforts. Competitor orientation is mainly focused on 1) people in charge of various services units discuss competitor information, 2) people in charge of various service units respond rapidly to competitors' actions, 3) top managers discuss competitors' strategies, and 4) top managers target opportunities for competitive advantage

Conceptually, competitor orientation means that a seller understands the short-term strengths and weaknesses, and long-term capabilities and strategies of both key current and potential competitors (Aaker, 1988; Day \& Wensley, 1988; Porter, 1980, 1985). Paralleling customer analysis, the analysis of principal current and potential competitors must include the entire set of technologies capable of satisfying the current and expected needs of the seller's target buyers (Levitt, 1960).

\subsubsection{Inter-functional Coordination}

The third one of the three core components of a market orientation is inter-functional coordination - the coordinated utilization of company resources in creating superior value for target customers. Any point in the buyer's value chain is an opportunity for a seller to create value for the buyer firm. This means that any individual in any function in a seller firm can potentially contribute to value creation. As Michael Porter (1985) explains, every department, facility, branch office and other organizational unit has a role that must be defined and understood. All employees, regardless of their distance from the strategy formulation process, must recognize their role in helping a firm achieve and sustain competitive advantage. To accomplish this effectively, companies have developed horizontal structures that focus on building values, such as time-to-market for new market orientation, customer value and superior performance.

Inter-functional coordination is mainly focused on 1) various service units work close together to meet customers' needs, 2) various service units share business information with each other, 3) business strategies are integrated between different service units, 4) all service units work together in offering value to the customer, and 5) different service units share resources with each other. A seller must draw upon and integrate effectively, as well as adapt as necessary, its entire human and other capital resources in its continuous effort to create superior value for buyers. Hence, that effort is the proper focus of the entire business and not merely of a single department in it (e.g., Webster, 1988). The coordinated integration of the business's resources in creating superior value for buyers is obviously tied closely to both customer and competitor orientation. Given the multidimensional nature of creating superior value for customers, marketing interdependencies with other business functions must be systematically incorporated in a business marketing strategy (Wind \& Robertson, 1983).

When there is no tradition of inter-functional coordination in a business, effective advocacy and leadership are needed to overcome each functional area's isolation from the other functions. Achieving effective interfunctional coordination requires, among other things, an alignment of the functional areas' incentives and the creation of inter-functional dependency so that each area perceives its own advantage in cooperating closely with the others. 


\subsection{Market Orientation and SMEs Performance}

Market orientation has been widely investigated because its firm performance outcomes are significant. Influential works were done by seminal researchers and writers in the area giving rise to solid theoretical background for such studies. For instance, marketing/market orientation has been linked to business outcomes such as sustainable competitive advantage (Narver \& Slater, 1990; Pelham \& Wilson, 1996), profitability (Narver \& Slater, 1990), new product innovation (Lukas \& Ferrell, 2000) and overall firm performance (Jaworski \& Kohli, 1993; Slater \& Narver, 1994). Adding to this, Foley and Fahy (2004) argue that the study of market orientation has tended to focus on the degree of market orientation exhibited by companies and the relationship between market orientation and performance.

Generally, because SMEs are less able than larger firms to shape their environment, they are compelled to acquiesce in response to environmental fluctuations (Tiessen et al., 2001). Whereas, as Hambrick (1983) notes, increased environmental dynamism brings SMEs both opportunities and threats, it can be suggested that a marketoriented culture works best in dynamic markets. This is because market oriented SMEs generally have greater capabilities for (1) identifying and meeting the changing needs and desires of customers, and (2) developing the necessary skills to respond properly to changing environmental conditions (e.g., Appiah-Adu \& Singh, 1998; Grewal \& Tansuhaj, 2001). As stated by Mohammed (2006), Borch and Huse, (1993), and Dandridge, (1979) argue that SMEs are not simply to be smaller copies of big ones' and there is a recognized need for concepts of strategic management that address the special characteristics and situations of small firms. In their conclusion, Alpkan et al. (2007) suggest that SMEs need to develop both a proactive market-oriented culture and a flexible process of strategic planning. The idea is that firms should transform both internally and externally from old concepts to the market concept to harvest the benefits of the concept. A review of small and medium sized enterprise (SME) marketing literature by Siu (2000), as cited in Ledwith and O'Dwyer's (2009), led to the conclusion that: 1) firms that prioritize marketing perform better than those that do not; 2) the input of marketing to the strategic planning process is significantly associated with the performance of small firms; 3) betterperforming companies define marketing activities as essentially customer oriented; 4) and 5) small-firm owners perceive customer orientation as critical to success.

It is on this ground that this piece of writing was proposed to test established hypotheses of high market orientation and improved firm performance indicators.

\section{Research Methodology}

The research considered a mix of descriptive and cause-effect designs. It tried to describe marketing/market orientation of SMEs in selected sub cities of Addis Ababa City Administration. It further attempted to investigate the determinants of market orientation of SMEs and its relationship with and its effect on firm level performance of such enterprises as important impetus for their development.

The study utilized secondary and primary data. The secondary data included reports and census surveys conducted at Addis Ababa and sub city levels. The primary data were collected through standardized questionnaire. The data were gathered from owner-managers and/or hired managers of the sample SMEs.

Addis Ababa City Administration was selected for the study because it fits for the purpose of the study. The manufacturing sector was selected purposely as this sector is believed to have competing marketing management philosophies. Enterprises in this sector can apply production, product, selling or marketing orientation. Therefore, studying this sector is much better and suitable for the objectives of the study than other sectors, such as services, construction, urban agriculture, and so forth. Next, three sub cities namely Kolfie, Gulele and Bole were selected based on the density of manufacturing SMEs in consultation with experts in the city's MSE Development Agency. Although it was difficult to obtain an accurate data on the population size of such enterprises in the city as well as the three sub cities, we determined 250 manufacturing SMEs as sample and then distributed them to the three sub cities and five sub sectors based on proportional sampling to population. Finally, we managed to collect data from 200 SMEs ( $80 \%$ response rate).

Data were collected through standardized questionnaire which contained items related to respondents' profile, internal characteristics of the enterprises, and constructs to measure market orientation and firm performance. The constructs were adopted from prior studies. All constructs were measured using seven-point Likert scales with strongly disagree $(=1)$ and strongly agree $(=7)$ anchors. Items for measuring market orientation were adopted from Narver and Slater (1990). This scale consists of items measuring the customer orientation (8 items), competitor(s) orientation (4 items), and inter-functional coordination ( 5 items) as components. Measurements of firm (SMEs) performance were also adopted from the same authors plus from Jaworski and Kohli (1993). Besides, data collectors were selected and trained.

The collected questionnaires were checked for neatness and accuracy and then, the data were fed into Statistical Package for Social Sciences (SPSS) software. For the quantitative analysis, different levels of analyses were made. In the first level, descriptive analyses were used using frequencies and percentage, average, and chisquare tests. Then, correlation analysis and multiple linear regression analyses were carried out to analyze the 
relationship between market orientation and firm performance constructs, and to investigate the determinants of market orientation and its effect on firm performance.

\section{Results and Discussions}

The data collected were processed through SPSS, and analyzed by using descriptive and inferential statistics. Before conducting the main analysis, reliability test was conducted to check the internal consistency of items used to measure customer orientation, competitor orientation, inter-functional coordination, overall market orientation, sales growth, long-term focus and survival and growth/profit emphasis.

Table 2: Reliability Test of Major Variables

\begin{tabular}{cccc}
\hline Variable & $\begin{array}{c}\text { Number of } \\
\text { Items }\end{array}$ & $\begin{array}{c}\text { Cronbach's } \\
\text { Alpha }\end{array}$ & $\begin{array}{c}\text { Conbach's Alpha Based on } \\
\text { Standardized Items }\end{array}$ \\
\hline $\begin{array}{c}\text { Customer Orientation } \\
\text { Competitor Orientation }\end{array}$ & 8 & 0.851 & 0.853 \\
Inter-functional Coordination & 4 & 0.792 & 0.793 \\
Overall Market Orientation & 5 & 0.830 & 0.830 \\
Sales Growth & 4 & 0.915 & 0.915 \\
Long-term Focus & 5 & 0.820 & 0.821 \\
Survival and Growth /Profit & 5 & 0.512 & 0.826 \\
Emphasis & & 0.937 & 0.938 \\
\hline
\end{tabular}

Source: Survey Data (2017)

The market orientation survey used in the current study consists of 31 items excluding demographic variables and SMEs' characteristics. The first three categories are market orientation variables that affect the other three. Customer orientation, competitor orientation and inter-functional coordination are hypothesized to affect sales growth, long-term focus and survival and growth/profit emphasis. The later three are considered as performance indicators. As indicated in Table 2, the Cronbach's Alpha of each category of the variables is in the range of the acceptable/accepted internal consistency of the respective items. As indicated in Table 2, the Cronbach's Alpha analysis of each category or variable showed a good level of internal consistency, for the results fell in the range of the acceptable level of internal consistency. In other words, the results of the analyses suggested that the items under each variable are highly related to each other to measure their respective or the same underlying concept. This is in line with studies conducted elsewhere in Africa (e.g., Boachie-Mensah \& Issau, 2015) and shows the reliability of the instrument.

\subsection{Respondents' Demographic Characteristics}

Basic data of the participants of the survey were collected. The data had both continuous and categorical nature. Thus, it is reported in summary statistics and frequency tables respectively. As indicated in Table 3 , the maximum age of the respondents is 58 years and the minimum is 20 resulting in an age range of 38 years. Interestingly, the mean age is 31.58 years which indicates that most of the respondents (operators) are in their adulthood stage and with reasonable experience of running successful enterprises.

Table 3: Distribution of Respondents by Age, Level of Education and Years in the Enterprise

\begin{tabular}{|l|c|c|c|c|c|}
\hline Variables & N & Min & Max & Mean & Std. Dev \\
\hline Age of the respondent & 200 & 20 & 58 & 31.58 & 5.609 \\
\hline Level of Education & 200 & 0 & 14 & 9.22 & 3.066 \\
\hline Year in the Enterprise & 200 & 1 & 13 & 3.47 & 2.453 \\
\hline
\end{tabular}

Source: Survey Data (2017)

The level of education of the respondents ranges from no formal education to 14 years of schooling. The mean schooling year is 9.22 years which shows the majority of the respondents possess educational level that is in commensurate with the requirements to run small businesses. The majority of the operators also had somewhat good experience ( 3.47 years on average) in their enterprises. 
Table 4: Distribution of Respondents by Gender, Marital Status and Position in the Enterprise

\begin{tabular}{|c|c|c|c|c|}
\hline Variable & & Frequency & Percent & $\begin{array}{l}\text { Chi-square } \\
(\mathbf{d f}=\mathbf{1})\end{array}$ \\
\hline \multirow[t]{3}{*}{ Gender } & Male & 145 & 71.4 & \multirow[t]{3}{*}{$40.5 * * *$} \\
\hline & Female & 55 & 28.6 & \\
\hline & Total & 200 & 100.0 & \\
\hline \multirow[t]{3}{*}{ Marital } & Married & 120 & 59.1 & \\
\hline & Single & 80 & 40.9 & \\
\hline & Total & 200 & 100.0 & \\
\hline \multirow[t]{4}{*}{ Position in the enterprise } & Owner (Manager) & 100 & 50.0 & \multirow[t]{2}{*}{$83.1 * * *$} \\
\hline & Employed Manager & 94 & 47.0 & \\
\hline & Missing & 6 & 3.0 & \\
\hline & Total & 200 & 100 & \\
\hline
\end{tabular}

Source: Survey Data (2017), *** statistically significant at $1 \%$

Gender wise, there was male dominance in the sample enterprise. This implies that jobs created in the small enterprises sector are open for males more than for females. This descriptive result was subjected to chi-square test and the difference in proportion of male and female operators is statistically significant. This result is in line with Tegegn and Mihret's (2010) findings in that males are dominant in manufacturing enterprises in the country. Quite significant proportions of the enterprises are managed by owner manager and the difference is statistically significant as indicated in the result of chi-square test. This is due to the fact that small enterprises are designed to primarily create self-employment, and there is no separation between the owner and the enterprise.

\subsection{Characteristics of the sample SMEs}

Enterprises of different characteristics were surveyed. Some of these characteristics are analysed and discussed as follows.

Table 5: Distribution of SMEs by Nature of Ownership, Type of Enterprise and Location

\begin{tabular}{|c|c|c|c|c|}
\hline \multicolumn{2}{|c|}{ Variable } & Frequency & Percent & Chi-square \\
\hline \multirow[t]{4}{*}{ Nature of Ownership } & sole proprietorship & 68 & 33.5 & \multirow{2}{*}{$(\mathrm{df}=2)$} \\
\hline & Partnership & 53 & 26.1 & \\
\hline & Cooperatives & 79 & 38.9 & \multirow[t]{2}{*}{$5.11 * *$} \\
\hline & Total & 200 & 100.0 & \\
\hline \multirow[t]{6}{*}{ Type of Enterprise } & Weaving & 39 & 19.2 & \multirow[t]{2}{*}{$(\mathrm{df}=4)$} \\
\hline & Stitching & 80 & 39.4 & \\
\hline & Leather & 46 & 22.7 & \multirow[t]{3}{*}{$66.35 * * *$} \\
\hline & Metal Work & 16 & 7.9 & \\
\hline & Furniture & 19 & 9.4 & \\
\hline & Total & 200 & 100 & \\
\hline \multirow[t]{4}{*}{ Location/Sub city } & Gulele & 64 & 31.5 & \multirow[t]{2}{*}{$(\mathrm{df}=2)$} \\
\hline & Kolfie & 77 & 37.9 & \\
\hline & Bole & 58 & 28.6 & $67.8 * * *$ \\
\hline & Total & 200 & 100 & \\
\hline
\end{tabular}

Source: Survey Data (2017), ** statistically significant at 5\%, *** statistically significant at 1\%

Slightly higher proportion of the enterprises is cooperatives (cooperatives of sole proprietors) in ownership followed by sole proprietorship. The differences in percentage of ownership types are statistically significant. This is a reflection of our business enterprises where the majority are family businesses and are operated by ownermanagers. Five important classifications, namely, weaving, stitching, leather, and metal and woodwork were randomly selected, and larger proportion was drawn from stitching and this is statistically significant. The proportion is based on the sample to population proportion method. The enterprises are located in Gulele, Kolfie and Bole where the majority of them were drawn from Kolfie sub city, which is statistically significant at $1 \%$.

Table 6: Descriptive Statistics on SMEs Characteristics

\begin{tabular}{|ccccccc|}
\hline Variable & N & Range & Minimum & Maximum & Mean & Std. Dev \\
\hline Number of Employees & 200 & 49 & 5 & 50 & 14.07 & 12.303 \\
\hline Average Monthly Sales & 200 & 25300 & 700 & 26000 & 5110.90 & 3848.477 \\
\hline Average Monthly Profit & 200 & 5865 & 100 & 5965 & 1230.32 & 1225.548 \\
\hline
\end{tabular}

Source: Survey Data (2017)

As depicted in Table 6, the largest number of employees hired by the sample SMEs is 50 and the minimum 
is 5. The sample SMEs have created job opportunities for some 14 individuals on average. The sample SMEs had a maximum average monthly sale of 26,000 Birr and a mean average monthly sale of 5110.90 Birr. In addition, the average monthly profit and mean average monthly profit of the sample SMEs are 5965 and 1230.32 Birr respectively. Thus, the sample SMEs created remarkable job opportunities and their average monthly sales and profit are encouraging though remarkable variations can be observed.

\subsection{Market Orientation and Performance of SMEs}

The market orientation construct consists of customer orientation, competitor orientation and inter-functional coordination. Two stage analyses were made to explore the extent of market orientation of SMEs. The first stage was computing the mean score of each construct and the second stage involved computing the overall market orientation mean score. As revealed in Table 7, the sample SMEs are slightly customer oriented and give moderate attention to inter-functional coordination as their market strategies. Contrary to this, the sample SMEs are less competitor oriented.

\section{Table 7: Market Orientation and Performance of SMEs}

\begin{tabular}{|c|c|c|c|c|c|}
\hline Variables & $\mathrm{N}$ & Min & Max & Mean & Std. Dev \\
\hline Customer Orientation & 200 & 1.00 & 7.00 & 4.5500 & 1.46032 \\
\hline Competitor Orientation & 200 & 1.00 & 7.00 & 3.9862 & 1.66647 \\
\hline Inter-functional Coordination & 200 & 1.00 & 7.00 & 4.2100 & 1.69133 \\
\hline Sales Growth & 200 & 1.00 & 7.00 & 5.0150 & 1.78045 \\
\hline Long term focus & 200 & 1.00 & 7.00 & 5.4560 & 1.70192 \\
\hline Profit emphasis & 196 & 1.00 & 7.00 & 5.3776 & 1.91434 \\
\hline Overall Market Orientation & 200 & 1.00 & 7.00 & 4.3174 & 1.38459 \\
\hline
\end{tabular}

Source: Survey Data (2017)

The sample SMEs are slightly market oriented in their production and marketing practices. These results are in conformity with previous empirical findings of elsewhere in Africa (e.g. Boohene et al., 2012). In connection with the investigation of SMEs' market orientation, their performance indicators were analyzed. Accordingly, the sample SMEs give slightly more emphasis to long term and survival objectives than to short term and/or intermediate sales growth.

Moreover, bivariate correlation analysis was conducted between the market orientation constructs and the performance indicators. The results indicated that there was statistically significant correlation between these variables.

Table 8: Correlation between Market Orientation and Performance Constructs

\begin{tabular}{|c|c|c|c|c|c|c|c|}
\hline & $\mathrm{MO}$ & $\mathrm{CO}$ & COMP & INTFUN & SALESGROWTH & LONGTERM & IPROFITEMPHASIS \\
\hline $\mathrm{MO}$ & 1 & & & & & & \\
\hline $\mathrm{CO}$ & $.921^{* *}$ & 1 & & & & & \\
\hline COMP & $.796^{* *}$ & $.596^{* *}$ & 1 & & & & \\
\hline INTFUN & $.884^{* *}$ & $.712^{* *}$ & $.604^{* *}$ & 1 & & & \\
\hline SALESGROWTH & $.310^{* *}$ & $.368^{* *}$ & $.230^{* *}$ & $.174^{*}$ & 1 & & \\
\hline LONGTERM & $.225^{* *}$ & $.253^{* *}$ & $.174^{*}$ & $.141^{*}$ & $.590^{* *}$ & 1 & \\
\hline PROFITEMPHASIS & $.318^{* *}$ & $.355^{* *}$ & $.190^{* *}$ & $.245^{* *}$ & $.751^{* *}$ & $.583^{* *}$ & 1 \\
\hline
\end{tabular}

Source: Survey Data (2017)

As shown in Table 8, there is strong and statistically significant relationship between the market orientation constructs. Customer orientation and overall market orientation had slightly higher correlation with the performance indicators used in the study. These results are in agreement with the hypotheses set and previous empirical findings indicated in the literature review (Boachie-Mensah \& Issau, 2015; Boohene et al., 2012).

\subsection{Determinants of Market Orientation of SMEs}

It was hypothesized that level of market orientation in SMEs is affected by several factors. These factors can emanate from operators or business structure of the enterprises. The following Table depicts regression results of the determinants of market orientation of the SMEs under study. 
Table 9: Regression Results for the Determinants of Market Orientation of SMEs

\begin{tabular}{|c|c|c|c|c|}
\hline$x^{2}+x^{2}$ & 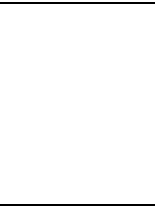 & 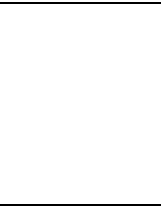 & \multirow{3}{*}{$\begin{array}{c}\begin{array}{c}\text { Standardized } \\
\text { Coefficients }\end{array} \\
\text { Beta }\end{array}$} & $\begin{array}{r}\text { R square }=0.379 \\
\text { square }=0.1430 \\
\text { S.E.E }=1.14496 \\
F(9)=2.846 \\
P V=0.0000\end{array}$ \\
\hline & \multicolumn{2}{|c|}{ Unstandardized Coefficients } & & \multirow[t]{2}{*}{ 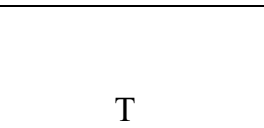 } \\
\hline & $\mathrm{B}$ & Std. Error & & \\
\hline (Constant) & 4.361 & .684 & & $6.379 * * *$ \\
\hline Age & .028 & .016 & .133 & $1.785 * *$ \\
\hline Gender & .335 & .202 & .124 & $1.658 * *$ \\
\hline Educational Status & .026 & .046 & .047 & $.575 * * *$ \\
\hline Position in the enterprise & .587 & .175 & .270 & $3.353 * * *$ \\
\hline Type of your enterprise & .076 & .113 & .074 & .672 \\
\hline Nature of ownership & .352 & .130 & .250 & $2.706 * *$ \\
\hline Number of employees & .030 & .010 & .308 & $2.870 * * *$ \\
\hline Average monthly profit & $4.353 \mathrm{E}-5$ & .000 & .045 & .550 \\
\hline
\end{tabular}

Source: Survey Data (2017), *** Statistically significant at $1 \%, * *$ statistically significant at $5 \%$

The model has a good fit to the dataset. With statistical significance of PV $=0.0000$, the variables in the model explained a variation of perceived market orientation of the enterprises understudy by 37.9 percent. As a result, six variables were found to have affected market orientation of the SMEs significantly. Three variables are related to operators' characteristics and the other three from enterprise features. When we look into the effect of each variable, an increase in age of operators by one year improves the perceived market orientation of the enterprises significantly at 5\%. Thus, age of the operators matters in making SMEs more market oriented. This is so because age increases marketing experience of operators and makes them more market centred in their business operations. Other things being constant, being male operator increases the perceived market orientation of SMEs in the study area by 0.335 , statistically significant at $5 \%$. Furthermore, as year of schooling of operators by one year, SMEs' perceived market orientation increases by 0.026 , other variables remain constant. Therefore, improving the level of education of operators in formal or informal education and training schemes could be important in improving market orientation and sustainable growth of SMEs in the country.

The other variable which affected market orientation of SMEs in the study area is position of operators in the enterprise. Accordingly, being hired manager of an enterprise increases market orientation of such enterprises by 0.587 , and it is statistically significant at $1 \%$. This might be so due to the fact that hired managers had professional training in management and business courses. Thus, it is crucial to professionalize management of SMEs in the country. Moreover, cooperative form of ownership has better and positive effect on market orientation. As a result, as we move from sole proprietorship form of ownership to cooperative form of ownership of the SMEs in the study area, the perceived market orientation of such enterprises increases by 0.352 , statistically significant at $5 \%$. Importantly, other things kept constant, as number of employees of the enterprises understudy increases by one employee, the perceived market orientation of such enterprises increases by 0.030 , statistically significant at $1 \%$. This indicates as enterprises expand and hire more employees, they become more and more market oriented in their business philosophy.

\subsection{Effect of Market Orientation on SMEs' Selected Performance Indicators}

One of the commonly linked outcomes with market orientation of firms in the literature is their performance. In this study, performance is measured in terms of sales growth, long-term focus and survival and growth/profit emphasis. We have selected these three indicators because there is a mixed impression on the impact of market orientation on firm performance. One line of argument is that market orientation has a positive impact on firm performance (Kotler, 2012). There is an opposite view in that market orientation confines firms to short term customer needs and short term sales and profit growth hampering long-term orientation of such firms. Therefore, taking these two positions in one piece of research and investigating the impact of market orientation on short and long term orientation of firms would add some useful insights to the existing literature. Indeed, as boldly suggested by Narver and Slater (1995), a market oriented firm will have a more satisfied customer base and this will translate into superior firm performance. Thus, the effect of market orientation of SMEs on their performance is analysed under this assumption. Linear regression was run to investigate the effect of market orientation and some operator related factors on enterprise performance indicators. The following Tables disclose the regression model fitness and analysis results. 
Table 10: Model Summary and Fitness

\begin{tabular}{|l|l|l|l|l|}
\hline Predicted & R square & Adjusted R square & F & Sig. \\
\hline Sales growth & 20.5 & 18.4 & 9.979 & 0.0000 \\
\hline Long term focus & 14.2 & 12.4 & 8.043 & 0.0000 \\
\hline Profit emphasis & 13.3 & 11.5 & 7.413 & 0.0000 \\
\hline
\end{tabular}

Source: Survey Data (2017)

The models have a good fit to the data. Table 11 presents the determinants of sales growth, long term focus and profit emphasis of the sample SMEs.

Table 11: Regression Analysis for Determinants of Enterprise Performance

\begin{tabular}{|c|c|c|c|c|c|c|c|c|c|}
\hline \multirow{3}{*}{$\begin{array}{l}\text { Independent } \\
\text { Variables }\end{array}$} & \multicolumn{3}{|c|}{ Sales growth } & \multicolumn{3}{|c|}{ Long term focus } & \multicolumn{3}{|c|}{ Profit emphasis } \\
\hline & \multicolumn{2}{|c|}{ Unstand. Coeff. } & \multirow{2}{*}{$\begin{array}{l}\text { Stand. } \\
\text { Coeff. } \\
\text { Beta }\end{array}$} & \multicolumn{2}{|c|}{ Unstand. Coeff. } & \multirow{2}{*}{$\begin{array}{l}\text { Stand. } \\
\text { Coeff. } \\
\text { Beta }\end{array}$} & \multicolumn{2}{|c|}{ Unstand. Coeff. } & \multirow{2}{*}{$\begin{array}{l}\text { Stand. } \\
\text { Coeff. } \\
\text { Beta }\end{array}$} \\
\hline & $\mathrm{B}$ & $\begin{array}{l}\text { Std. } \\
\text { Error }\end{array}$ & & $\mathrm{B}$ & $\begin{array}{l}\text { Std. } \\
\text { Error }\end{array}$ & & B & $\begin{array}{l}\text { Std. } \\
\text { Error }\end{array}$ & \\
\hline Age & .040 & .021 & $.127 *$ & .052 & .030 & $.114 *$ & .031 & .023 & .091 \\
\hline Gender & .697 & .265 & $.175 * * *$ & .342 & .391 & .060 & .368 & .301 & .085 \\
\hline $\begin{array}{l}\text { Years in } \\
\text { enterprise }\end{array}$ & -.149 & .057 & $-.205 * * *$ & & & & & & \\
\hline $\begin{array}{l}\text { Number of } \\
\text { employees }\end{array}$ & -.024 & .011 & $-.164 * *$ & -.063 & .014 & $-.304 * * *$ & -.026 & .011 & $-.164 * *$ \\
\hline $\mathrm{MO}$ & .397 & .082 & $308 * * *$ & .410 & .122 & $.223 * * *$ & .442 & .094 & $.316^{* * *}$ \\
\hline Constant & $2.38 * * *$ & .762 & & $2.91 * *$ & 1.127 & & $2.57 * * *$ & .870 & \\
\hline
\end{tabular}

Source: Survey Data (2017), *** Statistically significant at 1\%,** Statistically significant at 5\%,

* Statistically significant at $10 \%$

The sales growth of the sample SMEs is affected by age, gender and market orientation positively and significantly, whereas years in the enterprise and number of employees affect it negatively and significantly. The important finding here is as an enterprise's market orientation increases by one unit (mean score), sales growth increases by .308 unit (mean score). The finding supports the hypothesis set and is in agreement with previous empirical findings. For instance, Pelham (2000) also found out strong relationship between market orientation and overall performance of SMEs.

The long term orientation/focus of the sample SMEs is also affected by age of operators and market orientation positively and significantly. Contrary to this, number of employees affected it negatively and significantly. Similar, to the result in sales growth, market oriented SMEs focus on long term prospects of their enterprise. This is in line with the a priori expectation and empirical findings (Naver \& Slater, 1995). The profit emphasis of the sample SMEs is affected by market orientation positively and significantly, and negatively and significantly by number of employees.

In sum, other things being constant, market orientation of SMEs has significant and positive effect on the three performance indicators accounted in this study. This has several implications. Firstly, the result confirms the theoretical and empirical foundations of the study of market orientation (see the literature part). Practically, more market oriented SMEs would have superior performance and long term orientation.

\section{Conclusion and Recommendations}

Small and medium enterprises are important contributors to the overall development of nations alike. Their significance is paramount in developing countries in terms of job creation and poverty reduction. Thus, understanding their market orientation and its determinants on the one hand and the effect of market orientation on SMEs' performance on the other is vital to make their contributions substantial and sustainable. In this study, we tried to investigate the extent of market orientation of SMEs, the determinants of market orientation of SMEs and its impact on their performance by taking randomly selected SMEs from three sub cities in Addis Ababa City. The enterprises were mainly drawn from the manufacturing sector consisting textile, leather, and metal and woodwork. We have focused on the manufacturing sector only to generate deeper knowledge and understanding of market orientation and its effect on firm performance in the sector which is regarded by the government as a leading sector to transform the country's economy.

The findings of the study indicated that market orientation and its constructs have strong and significant relationships with the indicators of SMEs' performance. Moreover, market orientation was affected by operator related factors and business structures and features of the enterprises understudy. Importantly, market orientation of SMEs had significant and positive effect on the three performance indicators accounted in this study. In conclusion, the study has immense implications in terms of adding some insights to the existing body of literature because it tested some hypotheses held in the literature and generated confirmatory results. Thus, further studies 
in the Ethiopian context could benefit from the pertinent results of this study.

In practice, it may help SMEs' operators/managers know their level of market orientation and design strategies to make their enterprises more market oriented and balance between short- term and long-term focus in their firms' performance. The Government of Ethiopia (agencies organizing and supporting SMEs) could use results of the current study to formulate strategies peculiar to marketing trainings aiming at enhancing market orientation and thereby improving their performance and development. The current financial support and business development services provided by the government may not be suffice to make small businesses succeed in the ever increasingly competitive business environment without bringing meaningful changes in business philosophy and making the enterprises more market oriented.

However, the study is not without limitations as it is inherent in all researches. One prominent limitation of the current study is that it used respondents' perception of their firms' performance. It would have been more rigorous had it been possible to obtain accurate record of financial growth indicators such as sales and profit in quantitative terms at different points in time. Thus, it could be possible to see changes in sales or profit growth from time to time and analyze using level of market orientation. This was not possible in this study. Thus, future research could attempt to capture firm performance in quantitative terms. Non-financial performance of small and medium enterprises such as product development, technology adoption/development and market development are not accounted in the current study. Therefore, future studies could measure both financial and non-financial performances of such enterprises in conducting similar studies.

\section{References}

Aaker, David A., Douglas M. Stayman, and Richard Vezina (1988). "Identifying feelings elicited by advertising." Psychology \& Marketing 5.1: 1-16.

Adrianus Philip Schalk (2008). Effects of Market Orientation on Business Performance: Empirical Evidence from Iceland

Ajay K. Kohli, Bernard J. Jaworski, Ajith Kumar (1993). A Measure of Market Orientation: Journal of Marketing Research, Vol. 30, No. 4 (Nov., 1993), pp. 467-477 Published by: American Marketing Association

Alpkan, Lütfihak, Cengiz Yilmaz, and Nihat Kaya (2007). Market orientation and planning flexibility in SMEs: performance implications and an empirical investigation, International Small Business Journal 25.2: 152172.

Ann Ledwith and Michele O’Dwyer (2009). Market Orientation, NPD Performance, and Organizational Performance in Small Firms

Appiah-Adu, Kwaku, and Satyendra Singh (1998)."Customer orientation and performance: a study of SMEs." Management decision 36.6: 385-394.

Aregawi Ghebremichael Tirfe and Tilaye Kassahun (2014). Entrepreneurial Orientation as Growth Predictor of Small Enterprises: Evidence from Tigray Regional State of Ethiopia, Developing Country Studies, ISSN 2224-607X (Paper), ISSN 2225-0565 (Online),Vol.4, No.11

Becherer, Richard C.; Halstead, Diane; and Haynes, Paula J. (2003) "Marketing Orientation in SMEs: Effects of the Internal Environment," New England Journal of Entrepreneurship: Vol. 6: No. 1

Belay Kinati Debelo, Asmera Teshome, Tekalign Minalu (2015). Factors Affecting Developments of Micro and Small Enterprises: (Case of Mettu, Hurumu, Bedelle and Gore Towns of Ilu Aba Bora Administrative Zone), International Journal of Scientific and Research Publications, Volume 5, Issue 1, 1 ISSN 2250-3153

Bernard J.Jaworski and Ajay K.Kohli (1993). Market Orientation: Antecedents and Consequences, Journal of Marketing, volume 57 (July 1993, 53-70)

Boachie-Mensah, F. \& Issau, K. (2015). Market Orientation and the Performance of Small and Medium-Sized Manufacturing Enterprises in the Accra Metropolis, International Journal of Marketing Studies; Vol. 7, No. 3, ISSN 1918-719X E-ISSN 1918-7203, Published by Canadian Center of Science and Education

Boohene, R. Marfo-Yiadom and Yeboah (2012). An empirical analysis of the effect of entrepreneurial orientation on firm performance of auto artisans in the cape coast metropolis, Developing Country Studies, 2 (9), 7786.

Boohene, R., Agyapong, D., \& Asomaning, R. A. (2012). Micro level analysis of the market orientation-Small business financial performance nexus; American International Journal of Contemporary Research, 2(1)

Borch, Odd Jarl, and Morten Huse (1993). Informal strategic networks and the board of directors, Entrepreneurship theory and practice 18.1: 23-36.

Claire Gauzente (1999). Comparing Market Orientation Scales: A Content Analysis

Dandridge, Thomas C. "Children are not" little grown-ups": small business needs its own organizational theory." Journal of Small Business Management (Pre-1986) 17.000002 (1979): 53.

Day, George S., and Robin Wensley (1988). "Assessing advantage: a framework for diagnosing competitive superiority." Journal of marketing 52.2: 1-20.

Deshpande, Rohit, and Frederick E. Webster Jr (1989). Organizational culture and marketing: defining the research agenda." Journal of marketing 53.1: 3-15. 
Dey, P. (2012). "Incubation of Micro and Small Enterprises- an approach to Local Economic Development" International Journal of Scientific \& Engineering Research Volume 3, Issue 5, May-2012, ISSN 2229- 5518 IJSER (C) $2012 \mathrm{http}: / /$ www.ijser.org

Drysdale, L. (1999). Marketing or Market Orientation: What's the Difference, Prime Focus, The Professional Journal for Australian Primary School Leaders, pp28-29

Drysdale, L. and Gurr, D. (1998). The Impact of the Victorian Schools of the Future Self- management reform on the Measurement of School Performance and the Marketing of Schools, Paper ACEA Annual Conference, Gold Coast

Eshetu Bekele Worku (2008). Efficiency and Social Capital in Micro, Small and Medium Enterprises: The Case of Ethiopia, Unpublished PhD Dissertation, University of Western Cape

FDRE, MoFED (2010). Growth and Transformation Plan 2010/2011-2014/2015, Volume I: Main Text

FDRE, MoFED. (2006). A Plan for Accelerated and Sustained Development to End Poverty (PASDEP) (2005/062009/10), Volume I: Main Text. Addis Ababa. Ministry of Finance and Economic Development, Addis Ababa

FDRE, National Planning Commission (2015).The Second Growth and Transformation Plan (GTP II) (2015/162019/20)

FDRE, Ministry of Trade and Industry (1997). Micro and Small Enterprises Development Strategy,

Federal Micro and Small Enterprises development Agency (2011). Micro and Small Enterprises Development Strategy, Provision Framework and Methods of Implementation

Felton, Arthur P (1959). Making the marketing concept work. Harvard Business Review 37: 55-65.

Foley, A. and J., Fahy (2004). Towards a further understanding of the development of market orientation in the firm: a conceptual framework based on the market-sensing capability, Journal of Strategic Marketing, vol. $12,219-230$

Grewal, Rajdeep, and Patriya Tansuhaj (2001). Building organizational capabilities for managing economic crisis: The role of market orientation and strategic flexibility, Journal of marketing 65.2: 67-80.

Han,J.K., Kim,N., \& Srivastava,R.K (1998). Market orientation and organizational performance: is innovation a mission link? Journal of marketing, 62(4), 30-45

Helmsing, A. H. J (2003). Local economic development: New generations of actors, policies and instruments for Africa. Public Administration and Development: The International Journal of Management Research and Practice 23.1: 67-76.

Henard, D. H., and Szymanski, D. M. (2001). Why some new products are more successful than others, Journal of Marketing Research, Vol. 38 No.3, pp.362- 375.

Hibret Nigussie Tekle (2009). Impact of Business Development Services in Local Economic Development: the Case of Gullele Handloom MSE in City place Addis Ababa, Unpublished MA thesis, ISS, the Netherlands

Houston, F. S. (1986). The marketing concept: what it is and what it is not. Journal of marketing, 50(2), 81-87.

Jaworski, B. and Kohli, A. (1993). Market orientation: antecedents and consequences, Journal of Marketing, Vol. 57, pp. 53-70.

Joshi, V. And Gebreselassie Mihreteab (2016) Critical Success Factors of Micro \& Small Enterprises in Ethiopia: A Review, International Journal of Science and Research (IJSR) ISSN (Online): 2319- 7064

Kamalesh Kumar, Ram Subramanian, Charles Yauger (1998). Examining the Market Orientation-Performance Relationship: A Context-Specific Study, Journal of Management, Vol. 24, No. 2, 201-233

Keith, Robert J (1960). "The marketing revolution." Journal of marketing 24.3: 35-38.

Kohli, A. K. and Jaworski, B. J. (1990). Market Orientation: The Construct, Research Propositions, and Managerial Implications, Journal of Marketing, 54 (2), 1-18.

Kotler, P. Gary Armstrong (2012). Principles of marketing, $14^{\text {th }}$ ed, Pearson Prentice Hall,

Kotler, Philip and Alan R. Andearsen (1987). Strategic Marketing for non-profit organizations, $7^{\text {th }}$ ed, PrenticeHall

Kotler, Philip (1984). Marketing Management: Analysis, planning, Implementation, and Control, $5^{\text {th }}$ Edition, Prentice-Hall.

Ledwith, Ann, and Michele O'Dwyer (2009). Market orientation, NPD performance, and organizational performance in small firms, Journal of Product Innovation Management 26.6: 652-661.

Levitt, Theodore. Marketing myopia. Boston, 1960.

Lumpkin, G. and Dess, G. (2001). Linking two dimensions of entrepreneurial orientation to firm performance: The moderating role of environment and life cycle, Journal of Business Venturing, Vol. 16 No. 5, pp. 429451.

McKitterick, J (1957). What is the marketing thought and action, American Marketing Association, Chicago, IL: 71-82.

McNamara, Carlton P (1972). The present status of the marketing concept." Journal of marketing 36.1: 50-57.

Mesfin Seyoum Kebede (2015). Challenges and Prospects of Small Enterprises in Ethiopia: A Study of Entrepreneurs in Tigray Region, Unpublished PhD Dissertation, University of South Africa 
Mohammad Ziaul Hoq (2006). Effects of Organizational Resources on Organizational Performance: an Empirical Study of Bangladesh SMEs.

Mulat Demeke, Fantu Guta and Tadele Ferede (2006). Towards a more employment-intensive and pro-poor economic growth in Ethiopia: Issues and policies, Issues in Employment and Poverty Discussion Paper 22, By Employment Strategy Department, International Labour Office, Geneva

Munira Sherefa (2012). Performance of Micro and Small Enterprises and their Roles in Enhancing Local Economic Development: A Case Study in Gullele Sub City of Addis Ababa, Unpublished MA Thesis, Addis Ababa University

Narver, J. C. and Slater, S. F. (1990). The Effect of Market Orientation on Business Profitability, Journal of Marketing, 54: 20-35

National Bank of Ethiopia (NBE, 2015). "Annual Report 2014/15," National Bank of Ethiopia, Addis Ababa.

Olalekan Asikhia (2011). Adjusted Narver and Slater's Market Orientation Concept and Firm Performance in Nigerian Companies, Global Journal of Management and Business Research Volume 11 Issue 7 Version 1.0

Olumide Jaiyeobal and Donatus Amanze (2014). Testing the Applicability of Narver and Slater's Market Orientation Concept and Firm Performance in Botswana, Companies, Journal of Business Theory and Practice ISSN 2329-2644 Vol. 2, No. 1

Pelham, A. M., and D. T. Wilson (1996). A Longitudinal Study of the Impact of Market Structure." Firm Structure, Strategy, \& Market Orientation Market Orientation and Firm Value 541.

Pelham, Alfred M (2000). Market orientation and other potential influences on performance in small and mediumsized manufacturing firms. Journal of small Business Management, 38 (1), 48-67.

Peters, Thomas J., and Nancy Austin (1985). "A passion for excellence. The leadership difference."

Peters, Thomas J., Robert H. Waterman, and Ian Jones (1982). "In search of excellence: Lesson from America's best run companies

Porter, Lyman W., and Lawrence E. McKibbin (1988). Management Education and Development: Drift or Thrust into the 21st Century?. McGraw-Hill Book Company, College Division.

Porter, Michael E., and Victor E. Millar (1985). "How information gives you competitive advantage."

Richard C. Becherer, Diane Halstead and Paula Haynes (2001). Marketing Orientation in SMEs Effects of Internal Environment: 1-17 Journal of Research in Marketing \& Entrepreneurship: Vol. 3, Issue 1.

Siu, Wai-Sum (2000). "Marketing and company performance of Chinese small firms in Hong Kong." Marketing intelligence \& planning 18.5: 292-307.

Slater, Stanley F. and John C. Narver (1990). The effect of a market orientation on business profitability, Journal of Marketing

Slater, Stanley F, and John C. Narver (1994). "Market orientation, customer value, and superior performance." Business Horizons, p. 22+. Academic One File.

Slater, Stanley F., and John C. Narver (1998). Customer-led and market-oriented: let's not confuse the two." Strategic management journal 19.10: 1001-1006.

Slater, Stanley F., and John C. Narver (1995). Market orientation and the learning organization, Journal of marketing 59.3: 63-74.

Slater Stanley F. and John C. Narver (2000). The Positive Effect of a Market Orientation on Business Profitability: A Balanced Replication, Journal of Business Research 48, 69- 73

Solomon Worku Agaje (2004).Socio-economic Determinants of Growth of Small Manufacturing Enterprises in Addis Ababa, Unpublished Master Thesis Addis Ababa University

Szymanski, D. M. and Henard, D. H. (2001). Customer satisfaction: A meta-analysis of the empirical evidence. Journal of the academy of marketing science, 29(1), 16-35.

Tegegne Gebre-Egziabher and Meheret Ayenew (2010). Micro-and Small Enterprises as Vehicles for Poverty Reduction, Employment Creation and Business Development: The Ethiopian Experience, FSS Research Report No. 6

Tesfaye Abera Bokoro (2016). Survival Analysis of Small Scale Manufacturing Enterprises in Eastern Ethiopia, Journal of Scientific Research \& Reports 12(1): 1-12, 2016; Article no.JSRR.28332 ISSN: 2320-0227

Tiessen, James H., Richard W. Wright, and Ian Turner (2001). A model of e-commerce use by internationalizing SMEs, Journal of International management 7.3: 211-233.

Webster Jr, Frederick E (1988). "The rediscovery of the marketing concept." Business horizons 31.3: 29-39.

Wind, Yoram, and Thomas S. Robertson (1983). "Marketing strategy: new directions for theory and research." Journal of Marketing 47.2: 12-25.

Wrenn, B. (1997). The Market Orientation Construct: Measurement and Scaling Issues. The Journal of marketing Theory and Practice, 31-54

Yilmaz, C., Alpkan, L., \& Ergun, E. (2005). Cultural determinants of customer-and learning-oriented value systems and their joint effects on firm performance, Journal of business research, 58(10), 1340-1352.

Zeleke Worku (2013). Analysis of Factors That Affect the Long-Term Survival of Small Businesses in Pretoria, 
South Africa, Journal of Data Analysis and Information Processing, 2013, 1, 67-84 Published Online November 2013 (http://www.scirp.org/journal/jdaip) http://dx.doi.org/10.4236/jdaip.2013.14008 Open Access JDAIP

\section{About the Authors}

Alemseged Gerezgiher Hailu is an assistant professor of development studies at the Center of Rural Development, College of Development Studies, Addis Ababa University. He is also associate consultant at the Ethiopian Management Institute. His research interests include entreprenruship, small and medium enterprises, market access, food security, local economic development, social capital, socio-economic impact assessment, and rural poverty.

Tewodros Wuhib Woldemariam is an assistant professor in the Department of Management, Addis Ababa University. He is an independent Marketing consultant at Timex trading plc. His research interest is in the area of marketing (service quality, marketing practices, consumer buying behaviour,etc), entreprenuership, small and medium enterprises.

\section{Conflict of Interest}

We, the authors of this manuscript, declare that there is no conflict of interest between us and any third party.

\section{ACKNOWLEDGEMENT}

The authors are grateful to the Office of Director for Research, Addis Ababa University for sponsoring this study through its Adaptive Problem Solving Research Grant scheme. Grant number of this project was RD/P4-034/2016. Opinions reflected in the report/article are solely of the authors and do not represent the Office/University.

\section{Preferred Citation of the Article}

Alemseged Gerezgiher Hailu and Tewodros Wuhib Woldemariam (2019). Market Orientation in Small and Medium Enterprises: Determinants and Implications for Enterprise Development (Evidence from Addis Ababa, Ethiopia), Journal of $X X X$, Vol. (no.), pp 